\title{
Climatic Impacts of "Friagens" in Forested and Deforested Areas of the Amazon Basin
}

\author{
José A. Marengo and Carlos A. Nobre \\ Centre for Weather Forecasting and Climate Research (CPTEC), National Institute for Space Research (INPE), \\ Cachoeira Paulista, Sao Paulo, Brazil \\ Alistair D. CulF \\ Institute of Hydrology, Wallingford, Oxon, United Kingdom
}

(Manuscript received 29 September 1996, in final form 2 May 1997)

ABSTRACT

\begin{abstract}
Meteorological observations from the Anglo-Brazilian Amazonian Climate Observation Study (ABRACOS), together with the global reanalysis from the National Center for Environmental Prediction (NCEP) and satellite images, have been used to study the spatial extent and intensity of cold surges (known locally as "friagens") in the Amazon basin. Case studies are presented of two of the strongest events of the 1994 winter season: 26 June and 10 July 1994. In both events, daily minimum temperatures in southeastern Brazil dropped to near or below $0^{\circ} \mathrm{C}$, while at the same time minimum temperatures in southern Amazonia (Ji-Paraná site) were almost $8^{\circ} \mathrm{C}$ below average. Air temperature and humidity also fell in central and western Amazonia (Manaus and Marabá sites, respectively), although the fact that these reductions were less substantial than those farther to the south indicates that the cold air is greatly modified as it moves across Amazonia.

In Ji-Paraná the largest drops in minimum temperature coincided with strong winds from the south, implying that cold advection was the main mechanism for the falling temperatures. In contrast, there was no increase in wind speed at Manaus and Marabá during the days with reduced temperatures. At these sites, cooling was due to a reduction of the maximum temperature caused, at least partially, by increased cloudiness rather than by a lowering of minimum temperatures as at Ji-Paraná. With regard to the depth of the atmospheric boundary layer (ABL), it is observed that during the passage of the cold air in southern Amazonia, the ABL was cooler and shallower than during the pre- and postfriagem days. The friagens presented are of 5- to 6-day duration, including the passage of the cold front, but the period with cold temperatures lasts between 2 and 3 days.
\end{abstract}

\section{Introduction}

Surges of cold polar air that move across southeastern Brazil and the Amazon region from the south, greatly modifying the atmospheric structure and climatic conditions, are known locally as friagens (friagem in singular). These events can produce severe frosts in the coffee growing areas of southern Brazil and substantial cooling in the Amazon basin. The cold front heading these thrusts of polar air may reach as far north as the equator. The events are relatively common in the Amazon region during the winter (May-September). Culf et al. (1996) note that there were 6 such events in 1992 and 9 in 1993, while 14 events were reported during the winter of 1994. The dates of some friagens affecting Brazil over the period 1983 to the present are given in Table 1.

Corresponding author address: Dr. José Marengo, CPTEC/INPE, Rodovia Presidente Dutra Km. 40, 12630-000 Cachoeira Paulista, Sao Paulo, Brazil.

E-mail: marengo@cptec.inpe.br
Early work by Morize (1922) and Serra and Ratisbona (1942) describe the friagens as cold air masses from the south that manage to penetrate into the Tropics and affect Amazonia. They indicate that friagens can affect the southern part of Amazonia as well as the basins of the meridional tributaries of the Amazon, although they have never been reported in the states of northeast Brazil. Morize (1922) describes the cooling during the June 1920 friagem, in which he observed that the temperature dropped to $16^{\circ} \mathrm{C}$, causing the death of fish in lakes close to Manaus. Several papers have been devoted to the study of weather conditions during and preceding the friagens with emphasis on the synoptic and dynamic features and forecasting (see reviews in Marengo et al. 1997; Seluchi and Nery 1992; Satyamurty et al. 1990; Fortune and Kousky 1983). The economic impact of friagens on coffee production in southern Brazil is considered by Marengo et al. (1997) and Tarifa et al. (1985). To date, owing to the paucity of weather information at sufficiently high resolution in space and time, there have been fewer studies (Brinkmann and Goes-Ribeiro 1971, 1972; Marengo 1984; Fisch 1996; Nobre et al. 1996) of the impact of these cold surges in Amazonia. 
TABLE 1. Dates of some of the friagens affecting Brazil from 1983 to the present. Some of these events were very strong, while others produced only localized freezes in the mountain regions of southern Brazil. This compilation was made based on data from the several global and regional datasets described in section 2. Additional sources of information were Algarbe and Cavalcanti (1994), Dapozzo and Silva Dias (1994), and Fisch (1996).
7 June 1983
3 August 1983
24 August 1984
8 June 1985
2 June 1986
26 July 1986
19 June 1987
6 June 1988
13 July 1988
26 July 1988
7 July 1989
19 May 1990
22 July 1990
24 July 1992
15 June 1993
8 July 1993
1 August 1993
26 June 1994
9 July 1994
10 August 1994
19 April 1996
5 August 1996

Since 1990 the Anglo-Brazilian Amazonian Climate Observation Study (ABRACOS) see Gash et al. (1996) has been making continuous, hourly automatic weather station measurements at three locations within Amazonia with the main objective of providing reliable, long-term measurements of near-surface climate over forest and the deforested site (pasture or cleared forest) areas in the Amazon basin (Shuttleworth 1991). To achieve this aim, automatic weather stations (Didcot Instruments, Abingdon, United Kingdom), were installed in 1990 and 1991 at three locations, Manaus, Ji-Paraná, and Marabá (see Fig. 1), representative of central, western, and eastern Amazonia, respectively. At each of these locations measurements were made at both forested and deforested sites. Figure 2 shows the locations of the stations located in the forested and deforested ABRACOS sites.

The three ABRACOS sites were chosen to provide data on a range of Amazonian climatic conditions. Manaus, in Amazonas, in central Amazonia has a rainfall maximum around March to April and a minimum from July to September. Ji-Paraná, in Rondonia, is close to the southwestern border of the tropical rain forest and has a pronounced dry season between June and August. Marabá, in Pará, close to the eastern edge of the Amazon forest, has a pronounced dry season from June to September. Graphs of the average rainfall at each site are presented by Gash et al. (1996). Some general characteristics of the climate of both the forested and cleared sites are discussed by Culf et al. (1996) and Wright et al. (1996). These long-term datasets allow the penetra- tion of the friagens into Amazonia to be followed in much more detail than previously possible.

In the present paper, data from the three ABRACOS sites are used to investigate the intensity and penetration into Amazonia of two of the strongest outbreaks of polar air into Amazonia in the last $10 \mathrm{yr}$.

\section{Data}

The ABRACOS automatic weather station dataset provides continuous hourly records of air and wet bulb temperature, humidity, wind, precipitation, components of the radiation balance, and soil heat flux. At the forest sites, the weather stations were mounted above the forest canopy on the top of 45- to 50-m-high towers, while at the deforested sites the weather stations were mounted between 2 and $5.5 \mathrm{~m}$ above the surface. Full details of the sites and instrumentation are given by Culf et al. (1996).

In the present study, air temperature, wet bulb temperature, wind speed and direction, and incoming solar radiation at the surface for the periods 23 June to 1 July 1994 and 7 July to 15 July 1994 are used. There are two exceptions, however. Data from the forest at the Reserva Ducke, Manaus, were not available for the period 23 June-1 July, and no observations of wet bulb temperature were available at the forest site, Reserva Vale do Rio Doce, Marabá, for either of the two study periods. The values of water vapor pressure quoted in the present work were calculated from the air temperature and wet bulb temperature.

Data from three standard meteorological stations, Imperatriz, Porto Velho, and Santarem are used in addition to the ABRACOS stations. The locations of these sites

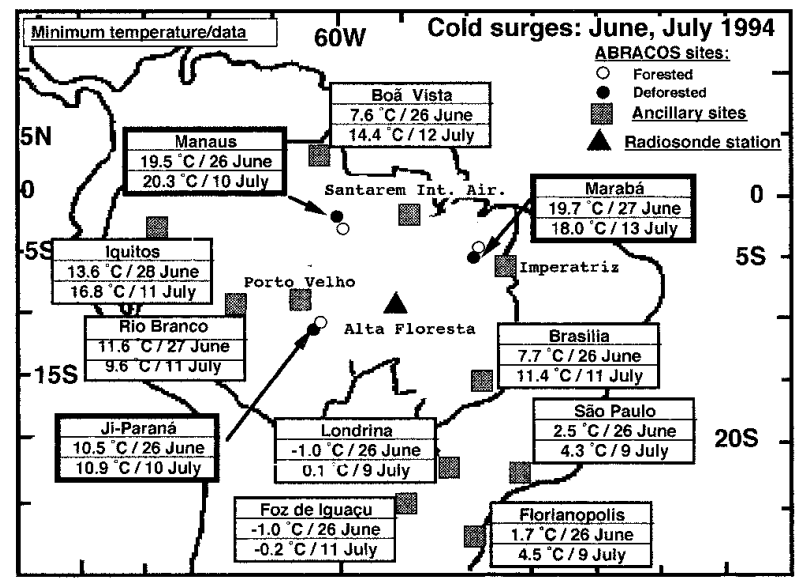

FIG. 1. Location of the ABRACOS sites: black dots indicated by arrows represent the "forested site," while the deforested site is depicted by white circles. Other ancillary stations in Amazonia and southeastern Brazil are indicated by gray squares. Radiosonde stations are indicated by a black triangle. For every station, information, such as the name of the station, and the lowest temperature and day of occurrence for both the June and July friagem events are next to each station dot or square. 
Friagem of 26 June, 1994

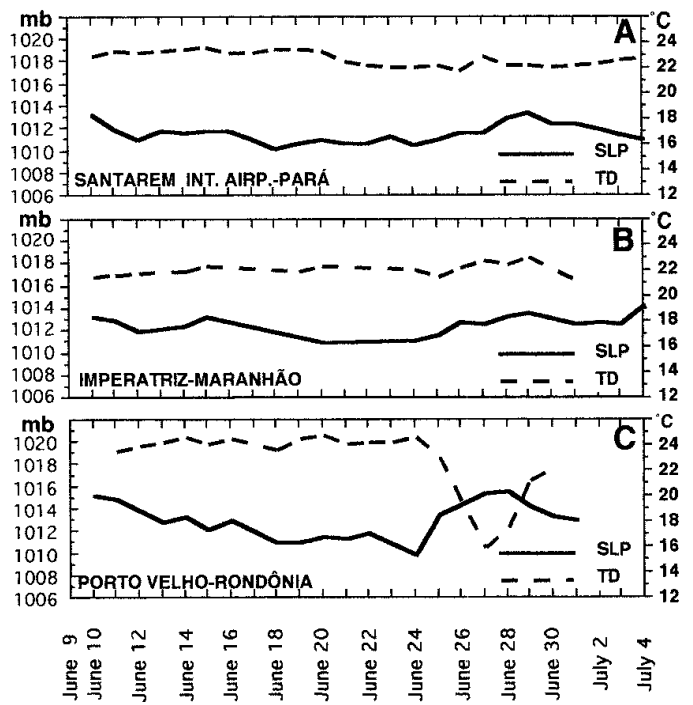

Friagem of 10 July, 1994

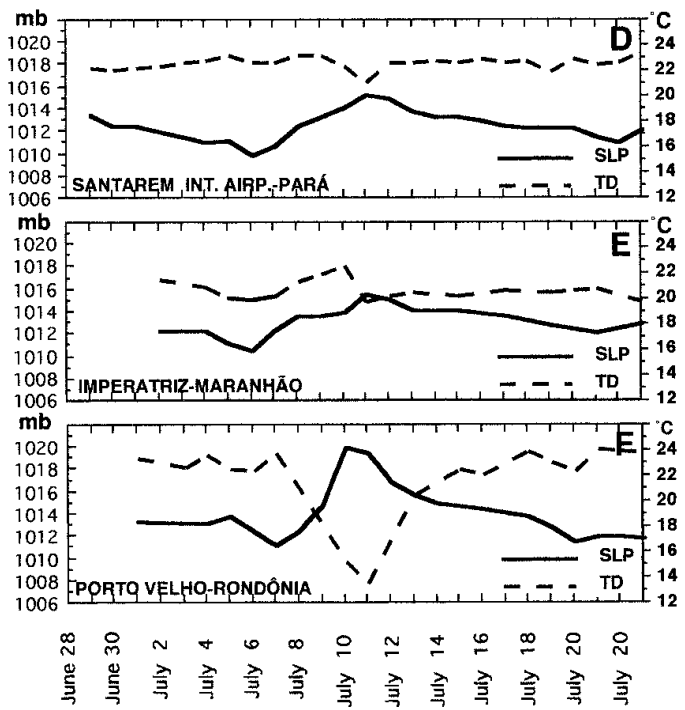

FIG. 2. Sea level pressure (solid line) and dewpoint temperature (dashed line) for 9 June-4 July (a)-(c) and 28 June-20 July 1994 (d)-(f) for Santarem International Airport, Imperatriz, and Porto Velho.

are shown in Fig. 1. Daily sea level pressure, dewpoint temperature, and minimum temperature data from these three stations has been used to identify the time of the passage of the cold front and lowest temperature associated with the friagem. These data are provided by the Brazilian Instituto Nacional de Meteorologia (INMET) and the National Climatic Data Center, from Asheville, North Carolina. In addition to these three stations, records of minimum temperature of eight meteorological stations in Amazonia and southeastern Brazil are used, to identify the spatial extent of the cold surges (Fig. 1).

To identify the large-scale and regional weather patterns associated with the presence of cold surges in Amazonia, surface and upper-air (1000, 925, 850, 700, $600,500,300 \mathrm{hPa}$ ) reanalyses of the National Centers for Environmental Prediction (NCEP)-National Center for Atmospheric Research (NCAR) (Kalnay et al. 1996) are used. These data are available at 6-h intervals and with an horizontal resolution of $2.5^{\circ} \times 2.5^{\circ}$.

Since the reanalysis data have only recently become available, there is only a rather small number of publications evaluating the analyses. According to V. Kousky (1996, personal communication), the monthly mean fields of basic variables (wind, air temperature, geopotential heights) are good. Apparently, there are sufficient observations to define the geostrophic features. He has analyzed a number of synoptic situations for the South American region, and despite some problems with model parameterizations and the diurnal cycle, the analysis seem to do a good job in depicting synoptic features. These reanalyses are an excellent resource for performing synoptic climatology studies (e.g., frequency and intensity of cold front intrusions in southern Brazil).
The extent of cloudiness associated with the friagens studied here is determined from specially enhanced infrared (IR) images from the Geostationary Operational Environmental Satellite (GOES), provided by the Instituto Nacional de Pesquisas Espaçiais (INPE) from São Paulo, Brazil. The images were taken at 1200 UTC and are available for the period between 24-28 June 1994 and 7-12 July 1994.

Daily data from radiosonde observations in southern Amazonia (Table 1, Fig. 1) are provided by the Divisão de Meteorologia Aeronautica, Rio de Janeiro, Brazil. The information was obtained from daily observations for the standard and significant levels for the 1200 UTC during the period 23-29 June 1994 only. Virtual potential temperature was calculated for each level from the available data.

\section{Surface observations}

Two examples of friagens are presented in the current work. Both were associated with low temperatures throughout Brazil and frost in the southern areas. Figure 1 shows some of the minimum temperatures and the dates that they occurred as reported by the INMET, for stations in Amazonia and southeastern Brazil during these two cold events. Minimum temperatures and dates are also shown at the three ABRACOS sites on the same figure. Economically, these two friagens had a severe impact. In the state of São Paulo, the Secretary of Agriculture estimated coffee production for 1995 and 1996 was reduced by $50 \%-55 \%$, due to the effects of the June and July 1994 friagens. In Paraná, after expectation of a 1995 to 1996 crop of between $120 \times 10^{6}$ and $150 \times 10^{6} \mathrm{~kg}$, 
Site: Jí-Paraná

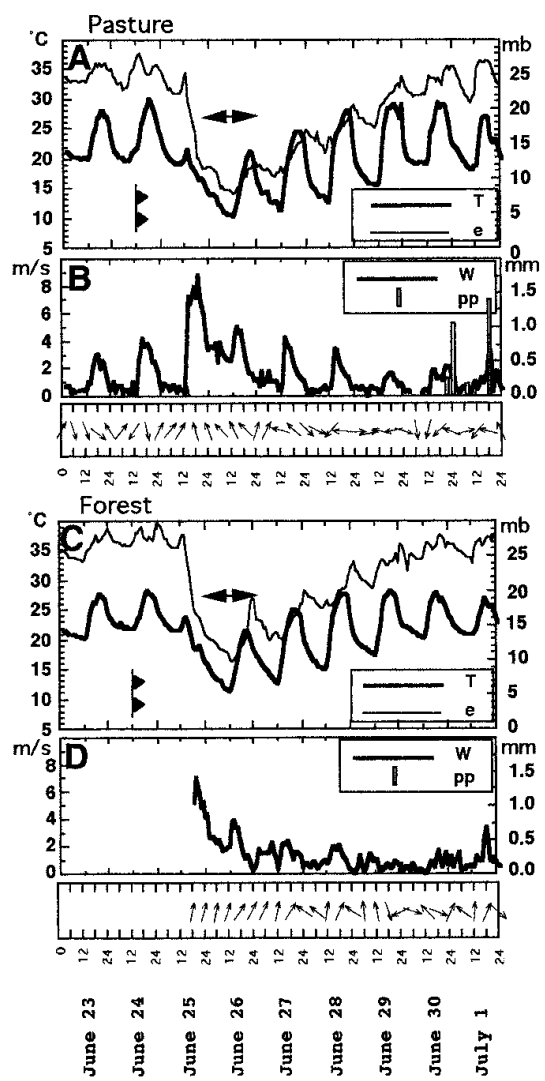

Site: Manaus

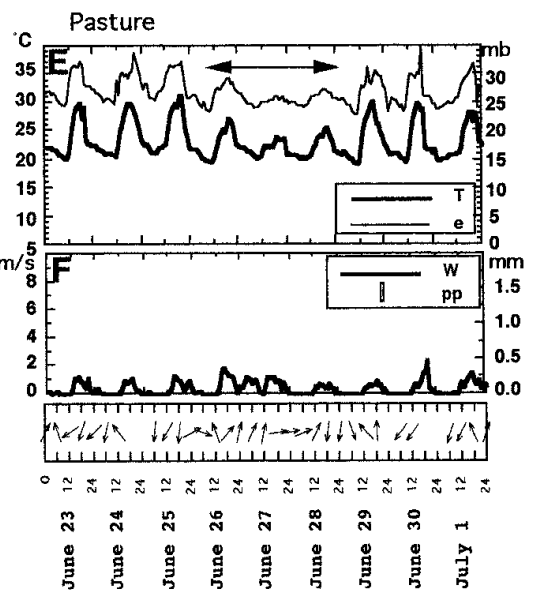

Site: Marabá

Pasture

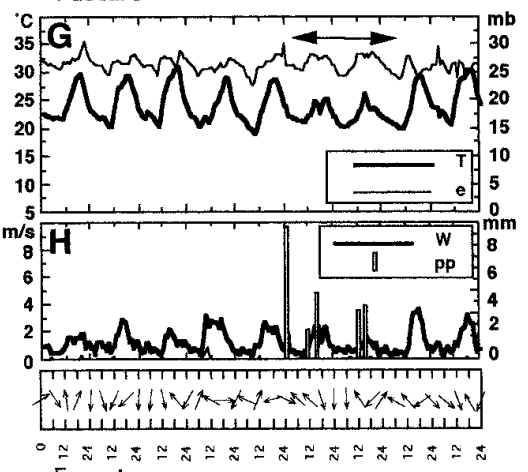

Forest

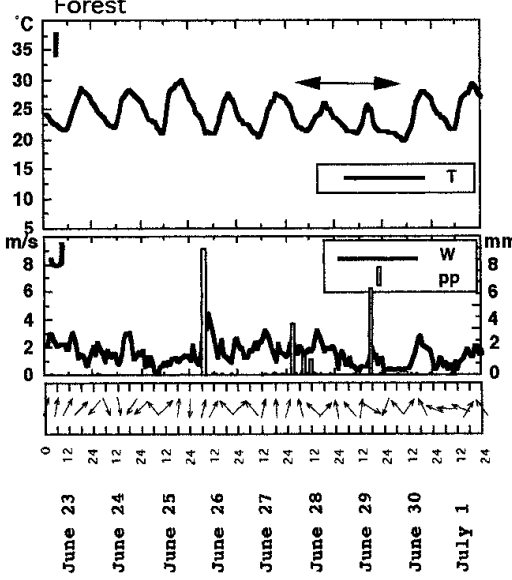

FIG. 3. Surface weather conditions at the surface at the Ji-Paraná, Manaus, and Marabá sites during the friagem of 26 June 1994. (a), (b), (e), (f), (g), (h) Data are for the deforested (pasture) sites, and the forested sites, (c), (d), (i), (j). (a) and (c) The position of the cold front is indicated. (a), (c), (e), (g), (i) The coldest days are marked with an arrow. (a), (b), (d), (e) The data are plotted from the hourly observations, while the wind direction is for every $6 \mathrm{~h}$ only. Hourly and daily scales are indicated in the lower panels. (a), (c), (e), (g), (i) The double scale are for air temperature $T\left({ }^{\circ} \mathrm{C}\right)$ and water vapor pressure $e(\mathrm{hPa})$ on the right and left sides, respectively. (b), (d), (f), (h), (j) Wind speed $W\left(\mathrm{~m} \mathrm{~s}^{-1}\right)$ and precipitation pp $(\mathrm{mm})$, on the right and left sides, respectively. The hourly timescale is UTC. To convert it to local time it is necessary to subtract $4 \mathrm{~h}$.

current forecasts after these two severe friagens are of only $15 \times 10^{6} \mathrm{~kg}$, more than $85 \%$ estimated losses.

The time of passage of the cold front is determined from changes in sea level pressure and dewpoint temperature at the ancillary stations. The amplitude of the changes indicates the degree of intensity of the phenomenon. Figure 2 shows that for the ancillary sites, the dewpoint and pressure curves have opposite trends during the friagens. The fall of the dewpoint temperature is fast, taking only $24-48 \mathrm{~h}$, whereas the return to normal takes more than $96 \mathrm{~h}$. The lowest dewpoint temperature occurs $48 \mathrm{~h}$ after the minimum pressure, that is, the passage of the cold front. In both case studies the clearest signal occurs in the data from Porto Velho (Figs. 2c,f), approximately $300 \mathrm{~km}$ from the Ji-Paraná site in southern Amazonia. Increases in pressure of up to $10 \mathrm{hPa}$ accompany the decrease in dewpoint by $12^{\circ} \mathrm{C}$ over 2 days. There is the same tendency at the other two ancillary stations, Santarem (Figs. 2a,d) and Imperatriz (Figs. 2b,e), although the signal is not as clear as in Porto Velho as the cold air is greatly modified by the time it reaches these two sites farther to the north. The passage of the cold front still results in a reduction in temperature at these sites, although the reduction is not as large as occurs in southern Amazonia or southern Brazil.

\section{Friagem of 26 June 1994-Surface and upper-air characteristics}

\section{a. Regional surface weather}

The passage of the cold front is very clear in the ABRACOS data from Ji-Paraná (Figs. 3a-d), compared to the time series from Marabá or Manaus. The front crosses the region on approximately 24 June, following which a cold air mass moves over the region leading to observations of low air temperature and humidity, with the lowest values occurring on the morning of 26 June. At the Ji-Paraná deforested site, air temperature dropped from $23^{\circ} \mathrm{C}$ on the afternoon of 25 June to $10.5^{\circ} \mathrm{C}$ on the morning of 26 June, and remained low until 28 June. By 29 June, temperature and humidity had reached the same 


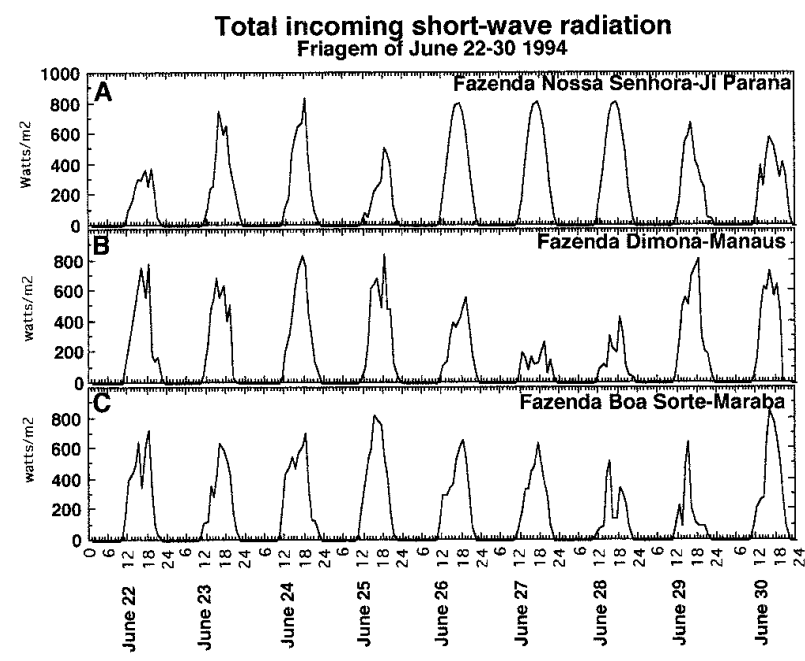

FIG. 4. Total incoming shortwave solar radiation $\left(\mathrm{W} \mathrm{m}^{-2}\right)$ at surface during the period 22-30 June 1994 for the three pasture sites. (a) Fazenda Nossa Senhora de Aparecida, Ji-Paraná, (b) Fazenda Dimona, Manaus, and (c) Fazenda Boa Sorte, Marabá. The hourly timescale is UTC. To convert it to local time it is necessary to subtract $4 \mathrm{~h}$.

levels that occurred before the passage of the cold front. During the coldest days, the wind was predominantly from the south, with speeds of almost $8 \mathrm{~m} \mathrm{~s}^{-1}$, twice the intensity of previous days (Fig. 3c). The winds increase in strength from 1200 UTC 25 June (approximately 0800 UTC local time) and remain strong until 1200 UTC 26 June, returning to normal values by early 27 June. This sequence is somewhat indicative of the steady entrance of cold air from southern latitudes during that period, some hours before the lowest minimum temperature, for a period of between 24 and $36 \mathrm{~h}$. At the Ji-Paraná forested site, a similar trend of temperatures, wind, and humidity to the pasture site is observed (Fig. 3d). The lowest temperature and humidity is recorded on the morning of 26 June $\left(11.3^{\circ} \mathrm{C}\right)$, dropping from a maximum of $22.5^{\circ} \mathrm{C} 24$ $\mathrm{h}$ previously. Figure $4 \mathrm{a}$ shows the time series of incoming solar radiation measured at the Ji-Paraná pasture site. Although there was some reduction in incoming solar radiation on 24 June associated with the passage of the front, the coldest day (26 June) and the following days were characterized by clear skies.

It is apparent from Fig. 3 that the friagem is relatively intense at both the forest and the deforested sites at Ji-Paraná. The magnitude of the changes in humidity, air temperature, and the wind speed and direction are comparable to the magnitude of those observed in stations in southeastern Brazil during the same cold event (Marengo et al. 1997).

In Manaus (Figs. 3e,f), cooling occurred from 26 to 29 June, with the coldest days being 26 and 29 June. The diurnal temperature range decreases on 26 June and becomes even smaller on 27 and 28 June, with a pronounced reduction of the maximum temperatures. This is in contrast to Ji-Paraná where both minimum and maximum temperatures were reduced substantially. Fig- ure $4 \mathrm{~b}$ shows that this cooling was associated with a decrease in incoming solar radiation, that is, an increase in cloudiness. Again, this is in contrast to the situation at Ji-Paraná where the lowest temperatures occurred under clear sky conditions. The maximum temperatures in Manaus are $5^{\circ}-7^{\circ} \mathrm{C}$ lower than on the days preceding the friagem. The atmospheric humidity is reduced between 26 and 29 June, rising back to normal values by 30 June. The wind speed throughout the period is light, less than $2 \mathrm{~m} \mathrm{~s}^{-1}$, but between 26 and 28 June, the wind has a predominantly southerly component. After that period the winds change direction constantly. All of these changes are indicative of the friagem, but the fact that they are all less marked than in Ji-Paraná indicates how the cold air surge has been greatly modified during its long passage over the Amazon basin.

In eastern Amazonia at Marabá (Figs. 3g-j) the signal of the friagem in the time series presented in Fig. 3 is weaker than at Manaus. The lowest temperatures occurred on 27 June $\left(19.4^{\circ} \mathrm{C}\right.$ at the deforested site). There is a small reduction in the diurnal temperature range between 28 and 29 June, largely the result of lower maximum temperatures than on the preceding days. Figure $4 \mathrm{c}$ shows that there was a decrease in the incoming solar radiation during this period. The passage of the cold front at this site is marked by rainfall rather than by a strong cooling and a reduction in humidity.

\section{b. Satellite images}

The main near-surface weather features during the 26 June friagem are shown in Figs. 5a-f. These images clarify the extent of the cloudiness associated with the cold front and the lack of cloudiness associated with anticyclonic conditions behind it and allow the passage of the system across South America to be followed quite clearly. The figures are based on GOES images for 1200 UTC, with some overlays added to identify the position of the cold core anticyclone and the cold front system before, during, and immediately after the coldest day. The fronts and pressure centers ( $\mathrm{H}$ denotes anticyclone, L denotes cyclone) are from the appropriate 1200 UTC NCAR-NCEP reanalysis at the surface.

From the $1000-\mathrm{hPa}$ sea level pressure from the NCAR-NCEP reanalysis for the 1200 UTC, the anticyclone is found to the west of the coast of southern Chile (on 23 June; Fig. 5a), with an intensity of 1034 $\mathrm{hPa}$. A well-defined frontal vortex $(990 \mathrm{hPa})$ is located over the coast of southern Argentina, with a frontal system stretching over southeastern Argentina and south of Uruguay. This frontal system is marked by low stratiform clouds over the adjacent ocean areas. An old front is found over southern Brazil. Cloudiness is observed over Ji-Paraná and Manaus, while another cold front is observed over southeastern Brazil. By 24 June (Fig. 5b), the anticyclone moves toward the coast of Chile, with an intensity of $1032 \mathrm{hPa}$. The cold front, with its associated cloud band, moved northward and is now 

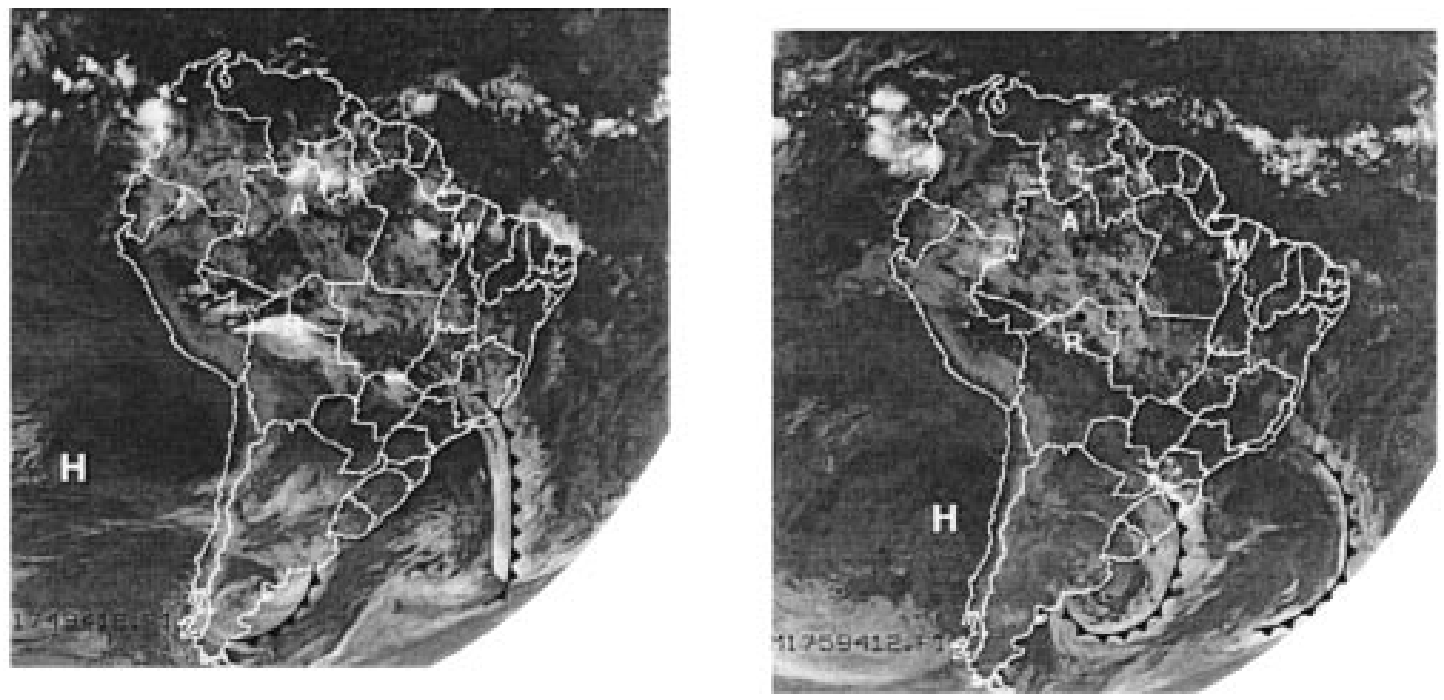

(a) $06 / 23 / 94,12$ UTC

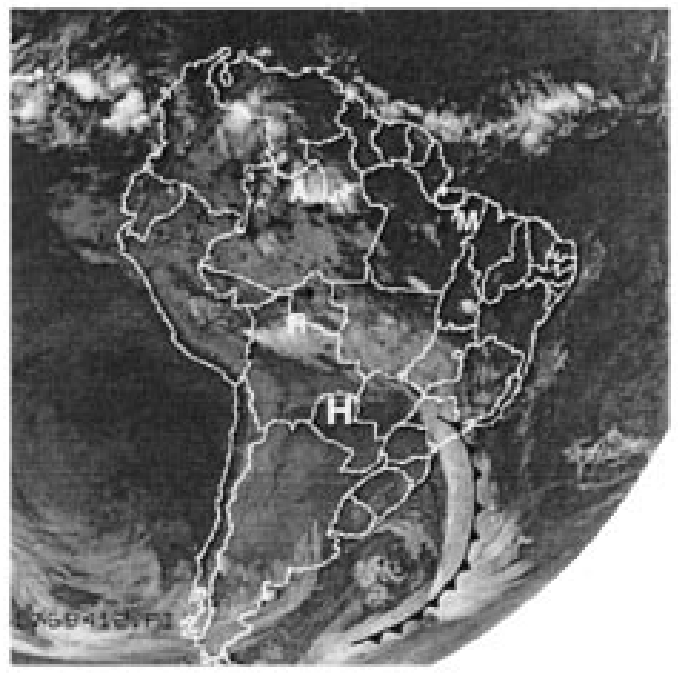

(b) $06 / 24 / 94,12$ UTC

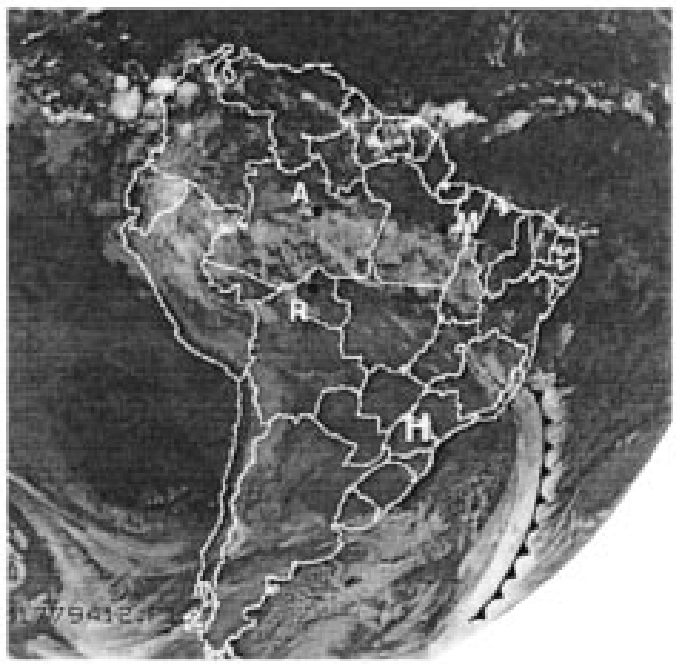

(c) $06 / 25 / 94,12$ UTC

(d) $06 / 26 / 94,12$ UTC

FIG. 5. Series of GOES-8 enhanced IR images, 1200 UTC for (a) 23 June, (b) 24 June, (c), 25 June, (d) 26 June, (e) 27 June, and (f) 28 June. Surface features such as the cold front and the anticyclone $(\mathrm{H})$ are from NCAR-NCEP reanalysis from 1200 UTC. The ABRACOS sites are indicated: Manaus (A), Marabá (M), and Ji-Paraná (R). 

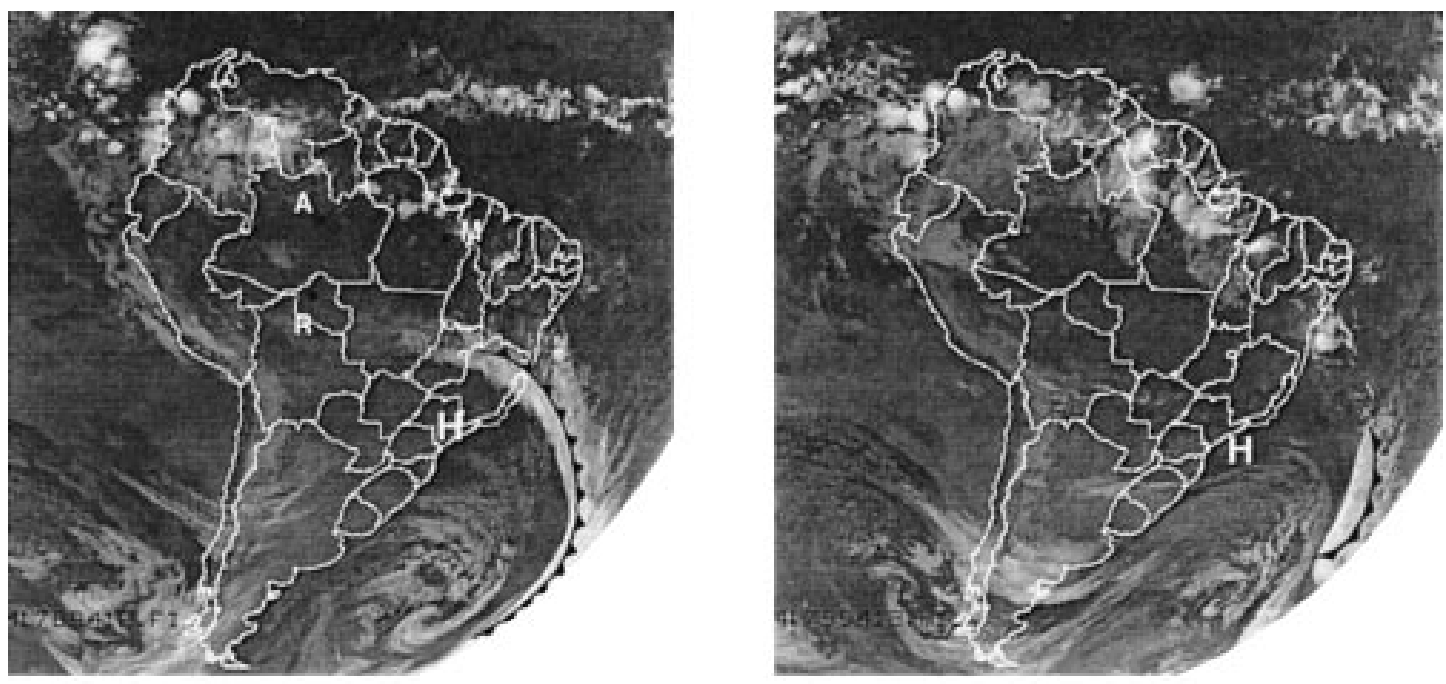

(e) $06 / 27 / 94,12$ UTC

(f) $06 / 28 / 94,12$ UTC

FIG. 5. (Continued)

placed over southern Brazil. Clouds cover Ji-Paraná and Marabá. On 25 June (Fig. 5c), after entering the continent over Patagonia and moving northward to a position bordering the east flank of the Andes, the anticyclone reaches its northernmost position at $22^{\circ} \mathrm{S}, 67^{\circ} \mathrm{W}$ with an intensity of $1030 \mathrm{hPa}$, and the cold front and its cloud band extend from the South Atlantic to Rondo̊nia, while Manaus is under clear conditions. Clear skies behind the cold front over southern Brazil and Uruguay indicate low temperatures for those regions during this day. On 26 June (Fig. 5d) the anticyclone had moved to the southeast $\left(25^{\circ} \mathrm{S}, 60^{\circ} \mathrm{W}\right)$, with a reduction of intensity to $1024 \mathrm{hPa}$ and with the cold front and related cloud band located over eastern Brazil around $12^{\circ}-15^{\circ} \mathrm{S}$. Clouds are also found over Manaus and Marabá, while Ji-Paraná is under clear skies. Clearing behind the front lead to a dramatic change in surface temperatures in southeastern Brazil (temperatures of less than $0^{\circ} \mathrm{C}$ were recorded on this day in Londrina and $\mathrm{Foz}$ de Iguazu; Fig. 1).

By this time, the frontal cloud band is composed mainly of middle and high-level clouds. By 27 June (Fig. 5e), the anticyclone moves to the east $\left(25^{\circ} \mathrm{S}, 62^{\circ} \mathrm{W}\right)$ with an intensity of $1024 \mathrm{hPa}$. The cold front and related cloud band is located over interior Brazil north of São Paulo. On this day and on 28 June (Fig. 5f), Manaus appears to be covered by middle-level clouds or shallow fair weather cumulus, as indicated by the reduced solar radiation and thermal range on those days. The anticyclone is located at $30^{\circ} \mathrm{S}, 57^{\circ} \mathrm{W}$, and the front is over the South Atlantic. There are cloudy skies over Marabá. c. Analysis of the 500- to 1000- (925-) hPa thickness layer

Studies on cold surges by Marengo et al. (1997) and Seluchi and Nery (1992) have used the 500-1000-hPa thickness layer to study the advance of the cold air. A thinner $500-1000-\mathrm{hPa}$ layer is an indication of the coldest average temperature at the atmospheric column and, during friagens, is usually found over southern Brazil or the nearby Atlantic, depending on the intensity of the event. The position of the largest horizontal gradient of this thickness field is an indicator of the area with the greatest advection of cooler air, usually southern Brazil and Argentina, while a smaller gradient is an indicator of a less intense event and is found over lower latitudes. Assessment of spatial and temporal variations of the 500-1000-hPa thickness layer is, therefore, helpful for determining how far the cold air intrusion advances into low latitudes.

The NCEP-NCAR reanalyses exhibit a significant smoothing in the fields of geopotential height, to remove spurious oscillations associated with postprocessing in regions with height elevation. Strong and well-defined cold air masses appear well depicted by the thickness layer until western Amazonia, while weak cold outbreaks appear to be diluted by the smoothing of the reanalyses (P. Silva Dias 1997, personal communication). Since the two cases studied here are characterized as strong (Marengo et al. 1997), we consider that the 500-925-mb thickness layers analyses are suitable for detection of cold air masses from southern Brazil to western Amazonia. 
Thickness of 500-925 hPa layer
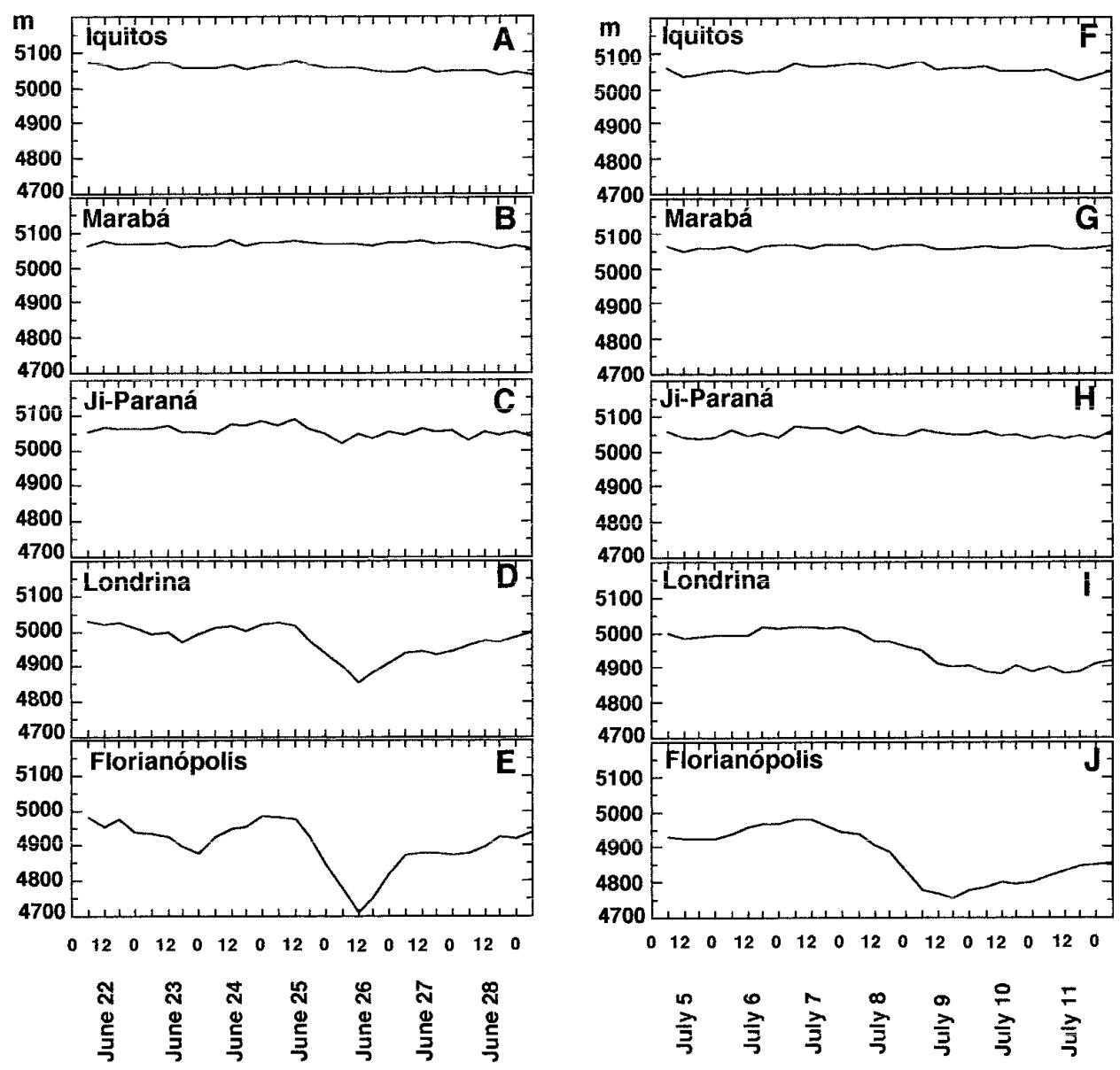

FIG. 6. Thickness of the 500-925-hPa layer for the period 22-28 June 1994 for the following locations: (a) Iquitos, Peru, (b) Marabá, Pará, (c) Ji-Paraná, Rondo̊nia, (d) Londrina, Paraná, and (e) Florianopolis, Santa Catarina. Thickness of the 500-925-hPA layer and for the period 5-11 July 1994 for the following locations: (f) Iquitos, Peru, (g) Marabá, Pará, (h) Ji-Paraná, Rondo̊nia, (i) Londrina, Paraná, and (j) Florianopolis, Santa Catarina. The data are from the NCEP-NCAR reanalysis and are ploted every $6 \mathrm{~h}$ (UTC).

The reanalyses are used to determine the 500-925hPa thickness for the Ji-Paraná and Marabá ABRACOS sites and for Iquitos, Londrina, and Florianopolis (see Fig. 1 for their locations). The values of the 500-925$\mathrm{hPa}$ thickness at each of these sites between 22 June and 28 June are plotted in Figs. 6a-g for the June event and Figs. $6 \mathrm{~h}-\mathrm{n}$ for the July event. These values were interpolated from the NCEP-NCAR maps. In southern Brazil (Florianopolis; Fig. 6g), the thickness layer decreases almost $300 \mathrm{~m}$ in $24 \mathrm{~h}$, reaching the lowest values on 26 June, the coldest day at surface (Fig. 1), while in southeastern Brazil (Londrina; Fig. 6d) the lowest values are reached on 26 June, decreasing by $200 \mathrm{~m}$ from 25 June. At the surface, temperatures of less than $0^{\circ} \mathrm{C}$ are reached at Londrina $\left(-1.0^{\circ} \mathrm{C}\right.$ on $26 \mathrm{June}$, as indicated in Fig. 1). The fact that even though the thickness of the 500- to $925-\mathrm{hPa}$ layer decreases more in Florianopolis than in Londrina, even though Londrina experiences colder temperatures at the surface, emphasizes how altitude and geographical location, especially with regard to proximity to the ocean, play important roles in determining surface conditions. In southern Amazonia (Ji-Paraná; Fig. 6c), the reduction of thickness between 25 and 26 June is almost $100 \mathrm{~m}$ and the average thickness is higher than in Londrina or Florianopolis, while for the rest of Amazonia (Figs. 6a,b) only Marabá shows a small reduction in thickness around 26 June with the other sites showing no change.

\section{d. Structure of the atmospheric boundary layer ( $A B L)$ in Amazonia}

Several experiments to observe the structure of the ABL over Amazonia have been carried out during the last decade. Among them are the Rondonia Boundary Layer Experiment (RBLE) and the NASA Amazon 


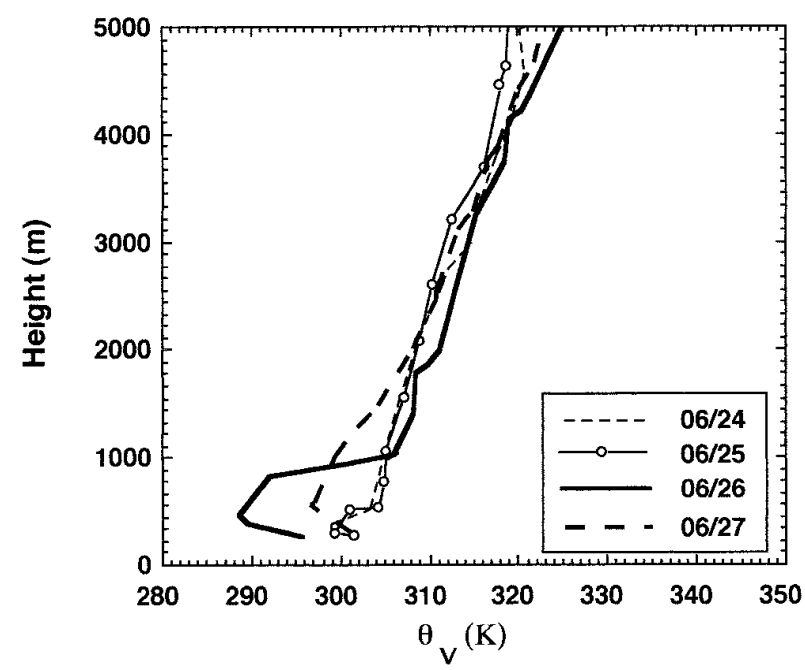

FIG. 7. Profiles of virtual potential temperature estimated from radiosonde observations at the site of Alta Floresta at 1200 UTC, for 24-27 June 1994.

Boundary Layer Experiment (ABLE-2A). These experiments were not specifically interested in the friagem and, unfortunately from the point of view of this study, RBLE-3 (13-25 August 1994) missed a strong friagem on 10 August and ABLE-2A (Martin et al. 1988) (July and August 1985) missed obtaining data from the most intense friagem of 1985 that occurred on 8 June.

However, during RBLE-2 [documented in Fisch (1996)], which was carried out in Ji-Paraná during the dry season of 1993 (July), a cold air mass moved across the region between 6 and 10 July modifying the atmospheric structure (Nobre et al. 1996). This friagem event was analyzed in detail by Fisch (1996), who describes a cooling of the entire ABL. Before the friagem on 5 July, the average temperature of the mixed layer was $307.8 \mathrm{~K}$ and the mixed layer depth (estimated as the depth of the layer in which the virtual potential temperature is constant with height) was $1350 \mathrm{~m}$ at 1700 local time. On 7 July, at the height of the event, the mixed layer only achieved a depth of $420 \mathrm{~m}$ by 1700 with an average temperature of $293.5 \mathrm{~K}$. This mixed layer is almost one-third of the typical value for the region. And in this day, with strong winds from the south, mechanical turbulence may have had a larger than normal contribution. After the passage of the cold front, sensible heat released by the surface is used to warm the ABL. An important finding of Fisch (1996) is that even after the passage of the cold air mass, the atmosphere still takes 2-3 days, depending on the intensity of the system, to get back to normal conditions.

Some of the thermodynamic characteristics of the ABL during the 26 June 1994 friagem can be studied by using the upper-air observations made in Alta Floresta (Fig. 1). Figure 7 shows the profiles of virtual potential temperature previous at 1200 UTC (approximately 0900 local time) before (24 and 25 June), during
(26 June), and after (27 June) the friagem. The upperair data for the site are only available for 1200 UTC, and so an analysis of the effect of the friagem on the mixed layer at the end of the day, as carried out by Fisch (1996) for the 1993 case, is not possible. However, the effect on the ABL can still be clearly seen in the 0900 LT data. On 24 and 25 June, the profiles of virtual temperature show a stable profile with surface heating beginning to create a convective layer at the surface. The residual layer between 300 and $800 \mathrm{~m}$ above the surface has an average temperature of $305 \mathrm{~K}$. During the friagem of 26 June, the profile up to $700 \mathrm{~m}$ above the surface has cooled dramatically from the preceding days. The profile shows again the beginning of the development of a convective layer at the surface, but above this layer, the average temperature between 200 and $700 \mathrm{~m}$ is 290 $\mathrm{K}$. This cold layer is separated from the profile above by a discontinuity in the virtual potential temperature of some $13 \mathrm{~K}$. On 27 June, the day following the friagem, the lowest $700 \mathrm{~m}$ of the profile have warmed by $8 \mathrm{~K}$ over the preceding $24 \mathrm{~h}$, with the lowest $200 \mathrm{~m}$ of the profile, where the influence of surface heating is strongest, having a similar temperature to that observed on 24 and 25 June. However, the cold layer now extends to $1600 \mathrm{~m}$ above the surface, with virtual potential temperatures in the 700-1600-m layer on average $3.5 \mathrm{~K}$ lower than on 24 and 25 June before the event.

\section{Friagem of 10 July $1994-$ Surface and upper- air characteristics}

\section{a. Regional surface weather}

The friagem of 10 July 1994 has similar characteristics to the 26 June event discussed above. The amplitude of the changes in temperature, dewpoint, solar radiation, and wind speed and direction are very similar to those observed at the three pairs of sites during the June event.

The cold front crosses the Ji-Paraná region on approximately 7 July, following which the air temperature and humidity steadily decreased, reaching their lowest levels on the morning of $10 \mathrm{July}\left(10.5^{\circ} \mathrm{C}\right.$ over the deforested site and $10.9^{\circ} \mathrm{C}$ over the forest; Figs. 8a,c). The minimum temperature and humidity started to decrease on 9 July at both the Ji-Paraná sites, with the largest decrease between 9 and 10 July. The wind speed increases (7-8 $\mathrm{m} \mathrm{s}^{-1}$ compared to the $2-3 \mathrm{~m} \mathrm{~s}^{-1}$ of preceding days) on 9 July, one day before the coldest day, and remaines strong and from the south until early morning of 10 July (Figs. 8b,d). Figure 9a shows the time series of incoming solar radiation measured at the Ji-Paraná pasture site. Although there is some reduction in incoming solar radiation on 8 and 9 July associated with the passage of the front, the coldest day (10 July) and the following days were characterized by clear skies, which is confirmed by the large diurnal thermal 
Site: Ji-Paraná
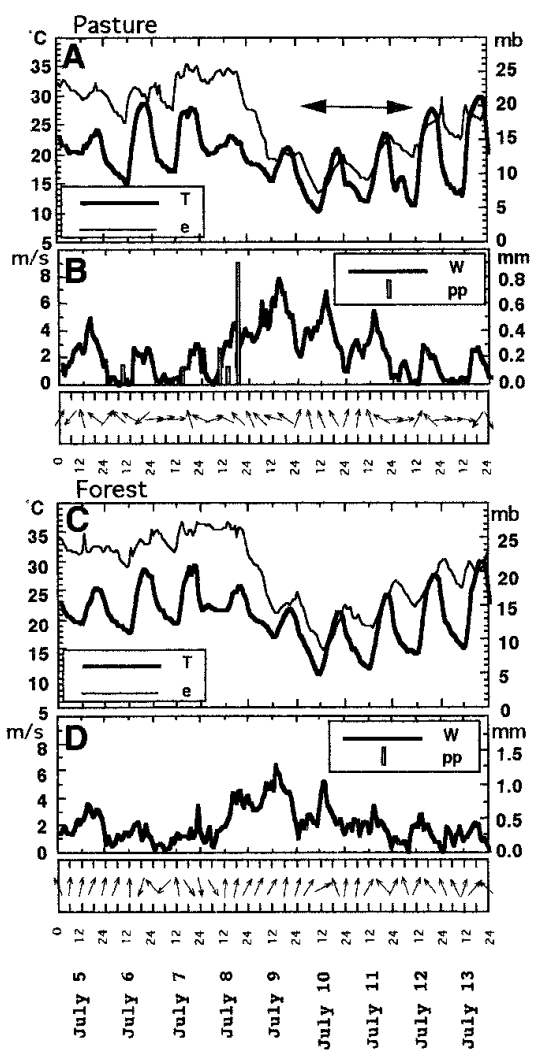

Site: Manaus
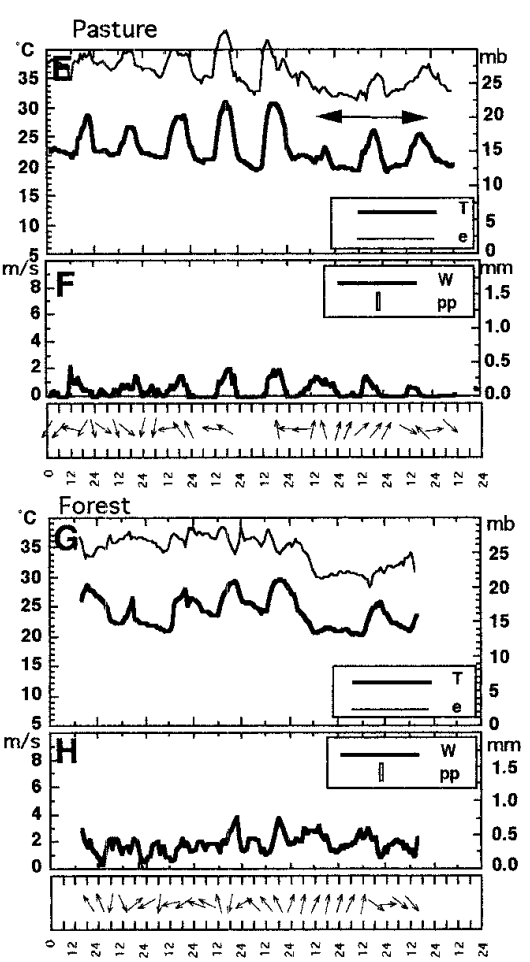

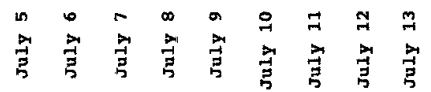

\section{Site: Marabá}

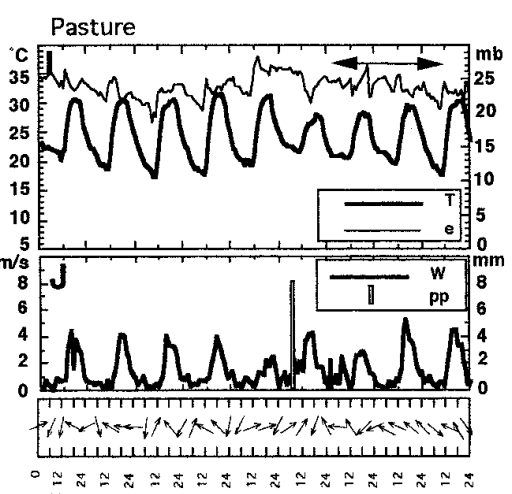

Forest

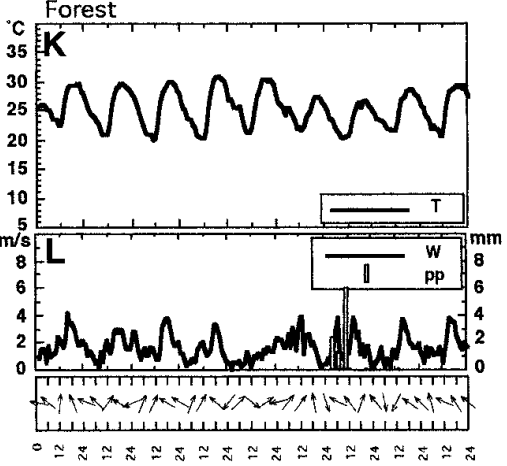

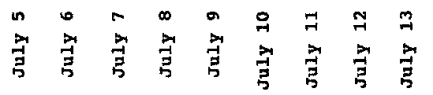

FIG. 8. Surface weather conditions at the surface at the Ji-Paraná, Manaus, and Marabá sites during the friagem of 9-10 June 1994. (a), (b), (e), (f), (i), (j) Data are for the pasture and the forested sites (c), (d), (g), (h), (k), (l). (a) and (c) The position of the cold front is indicated. (a), (e), (i) The coldest days are marked with an arrow. (a), (b), (c), (e), (f), (g), (i), (j), (k) The data are plotted from the hourly observations, while the wind direction is for every $6 \mathrm{~h}$ only. Hourly and daily scales are indicated in the lower panels. (a), (c), (e), (g), (i), (k) The double scale are for air temperature $T\left({ }^{\circ} \mathrm{C}\right)$ and water vapor pressure $e(\mathrm{hPa})$ on the right and left sides, respectively. (b), (d), (f), (h), (j), (1) Wind speed $W\left(\mathrm{~m} \mathrm{~s}^{-1}\right)$ and precipitation pp (mm), on the right and left sides, respectively. The hourly timescale is UTC. To convert it to local time it is necessary to subtract $4 \mathrm{~h}$.

range on those days (Fig. 8a), especially the larger maximum temperatures.

In Manaus, central Amazonia, the lowest minimum temperatures are observed on 11 July $\left(20.3^{\circ}\right.$ and $20.6^{\circ} \mathrm{C}$ at the pasture and forested sites, respectively; Figs. 8e,g), with sudden drops in temperature and atmospheric moisture from 10 to 11 July. The winds become stronger the day before the coldest day and have a southerly component, but they are much weaker than at Ji-Paraná (Figs. 8 f,h). During 10, 11, and 12 July, the thermal diurnal range is quite reduced, as compared to previous days, which is related to increased cloudiness, as deduced from the low solar radiation data (Fig. 9b) on those days.

At Marabá, it is more difficult to find the signal of a friagem in the temperature and humidity records. The temperature falls on 11 July and the coldest day was on 13 July (Figs. 8i,k). The winds are not much stronger than normal and the direction is more variable than at Ji-Paraná or Manaus (Figs. 8j,l). The steady southerly flow observed in Ji-Paraná, and to a lesser degree in Manaus, is not apparent. Overall, the signal of the friagem is much weaker in Marabá for this 10 July case than for the 26 June event discussed above. Solar radiation at Marabá (Fig. 9c) indicates that on 13 July, the coldest day, the diurnal thermal range was large and clear skies are registered on that day, and the minimum temperature decreases while the maximum temperature is even higher than on previous days. This behavior is in contrast with the lower maximum temperature and cloudy skies recorded at the same place for the June event (Figs. 3g, 4c).

\section{b. Satellite images}

Figures 10a-f shows the GOES images at 1200 UTC, with the overlays added to identify the position of the cold core anticyclone and the cold front system before, during, and immediately after the coldest day, as in the June 1994 case explained in Figs. 10a-f. From the 1000$\mathrm{hPa}$ sea level pressure from the NCAR-NCEP reanalysis for 1200 UTC, the anticyclone is found to the west of the coast of southern Chile at $50^{\circ} \mathrm{S}, 77^{\circ} \mathrm{W}$ (on 7 July; Fig. 10a), with an intensity of $1032 \mathrm{hPa}$. To the northeast 


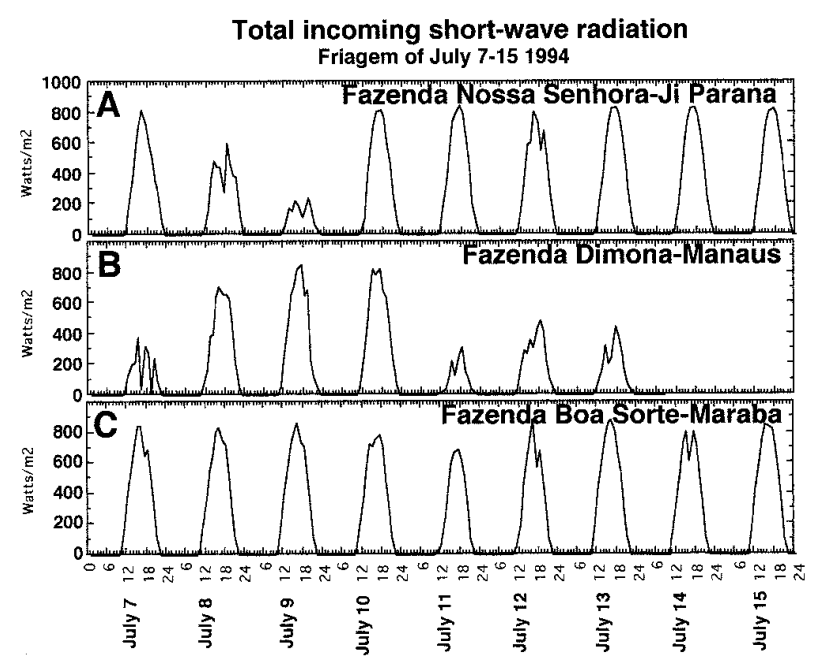

FIG. 9. Total incoming shortwave solar radiation $\left(\mathrm{W} \mathrm{m}^{-2}\right)$ at surface during the period 7-15 July 1994 for the three pasture sites. (a) Fazenda Nossa Senhora de Aparecida, Ji-Paraná, (b) Fazenda Dimona, Manaus, and (c) Fazenda Boa Sorte, Marabá. The hourly timescale is UTC. To convert it to local time it is necessary to subtract $4 \mathrm{~h}$.

of that anticyclone, a low pressure center $(1014 \mathrm{hPa})$ is associated with a frontal system in formation over southern Brazil. Cloudiness is observed over central Amazonia. Figure 10a shows also the location of the cold front entering southeastern Brazil.

By 8 July (Fig. 10b) the anticyclone has entered the continent over Patagonia and moved northward to a position bordering the east flank of the Andes $\left(45^{\circ} \mathrm{S}\right.$, $\left.70^{\circ} \mathrm{W}\right)$, and affecting Argentina with an intensity of $1034 \mathrm{hPa}$. The cold front with its associated cloud band has moved northward and is now placed over São Paulo. Relatively clear skies are found over the three sites. On 9 July (Fig. 10c) the anticyclone is located over central Argentina $\left(35^{\circ} \mathrm{S}, 70^{\circ} \mathrm{W}\right.$, intensity of $\left.1038 \mathrm{hPa}\right)$ and affecting southern Brazil. The cold front and its cloud band extend from the South Atlantic reaching north of São Paulo. Ji-Paraná is affected by low and middle clouds (confirmed by the low solar radiation on this day; Fig. 4a), while Manaus and Marabá are under clear conditions. Clear skies behind the cold front over southern and southeastern Brazil indicate the lowest temperatures for those regions during this day.

On 10 July (Fig. 10d), the anticyclone, with slightly reduced intensity $(1036 \mathrm{hPa})$ is located between north Argentina and Bolivia $\left(25^{\circ} \mathrm{S}, 65^{\circ} \mathrm{W}\right)$, and the cold front is weak and extending from the low pressure center over the South Atlantic to the south of northeast Brazil. Clearing behind the front lead to a dramatic change in surface temperatures in southern Amazonia (temperatures of almost $10^{\circ} \mathrm{C}$ were recorded on this day in Ji-Paraná and Manaus, with clear skies at the three ABRACOS sites). By 11 July (Fig. 10e), the anticyclone has moved a little farther to the northeast $\left(27^{\circ} \mathrm{S}, 65^{\circ} \mathrm{W}\right)$ with an intensity of $1036 \mathrm{hPa}$, and the cold front and related cloud band is located over the ocean away from the continent. On 12 July (Fig. 9f), the cold front has dissipated and the anticyclone, reduced in intensity, is located off the coast of south and southeastern Brazil. On this day and on 11 July, Manaus appears to be covered by middle-level clouds or shallow fair weather cumulus, as indicated by the reduced solar radiation and thermal range on those days, while clear skies are detected over over Marabá and Ji-Paraná. Culf et al. (1996) have indicated that smoke from the pasture burning may also have the effect of reducing the input of solar radiation over the pasture areas, and the observations should be interpreted with caution.

\section{c. Analysis of the 500- to 1000- (925-) hPa thickness layer}

For the July event, in southern Brazil the decrease of the thickness layer is much larger than in Amazonia, even though it is relatively smaller than that of the June event for the same locations. Thickness in Florianopolis (Fig. 6j) deepened almost $250 \mathrm{~m}$ from 7 July to 9 July (the coldest day), while in June the decrease was more than $300 \mathrm{~m}$ in 1 day. The decrease in thickness in Londrina (Fig. 6i) was smaller than in June, consistent with the minimum air temperatures on those days $\left(-1.0^{\circ} \mathrm{C}\right.$ on June $26,0.1^{\circ} \mathrm{C}$ on July 9 ).

No change in the thickness of the 500- to $925-\mathrm{hPa}$ layer is observed at Ji-Paraná (Fig. 6h) or for the rest of Amazonia (Figs. 6f-g). This is in contrast to the June event when changes were observed at these stations. This observation, along with the minimum air temperature data, indicates that the July event was weaker than the June event discussed above. The thickness layer does not show any variation, as in the June event, meaning that the air mass did not reach southern Amazonia as strongly as in the June event.

This analysis of the thickness layer is not intended to depict the depth of the cold air intrusion, but just to indicate the progress of the cold air from higher to lower latitudes. The data confirm that the cold surge that intensely affected southern and southeastern Brazil on 26 June extended its effects to southern Amazonia, and in much less degree to Manaus, while being almost unfelt in the rest of Amazonia.

\section{Summary}

To summarize the characteristics of surface weather described in sections 4 and 5, it is noticed that in both cold events, weather measurements over the forested and deforested sites have detected the passage of the cold and dry air, with more intensity in southern Amazonia, as compared to the sites located at the central or eastern sections of the basin. Both the forested and deforested sites showed an increase of wind speed from the south before and during the coldest day. The minimum air temperatures at the deforested site are $0.5^{\circ}-$ $2.0^{\circ} \mathrm{C}$ lower than over the forests, while minimum tem- 


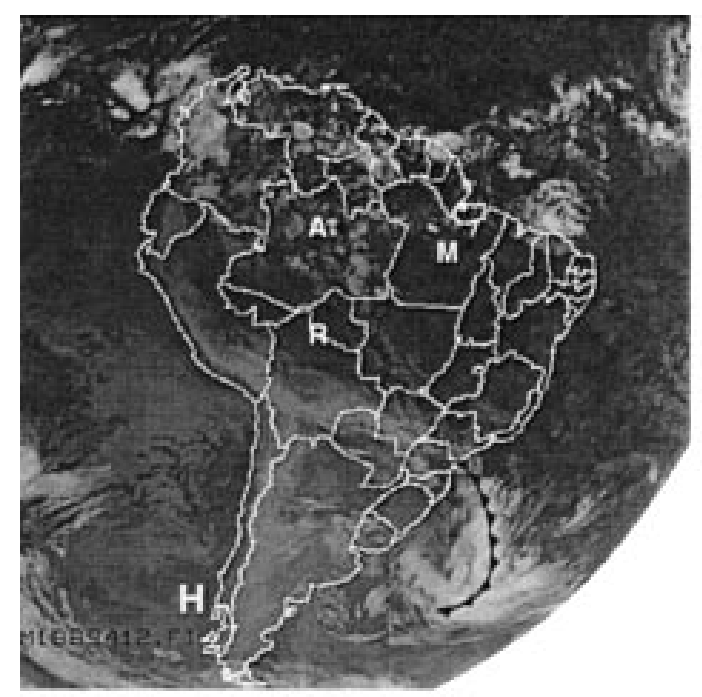

(a) $07 / 07 / 94,12$ UTC

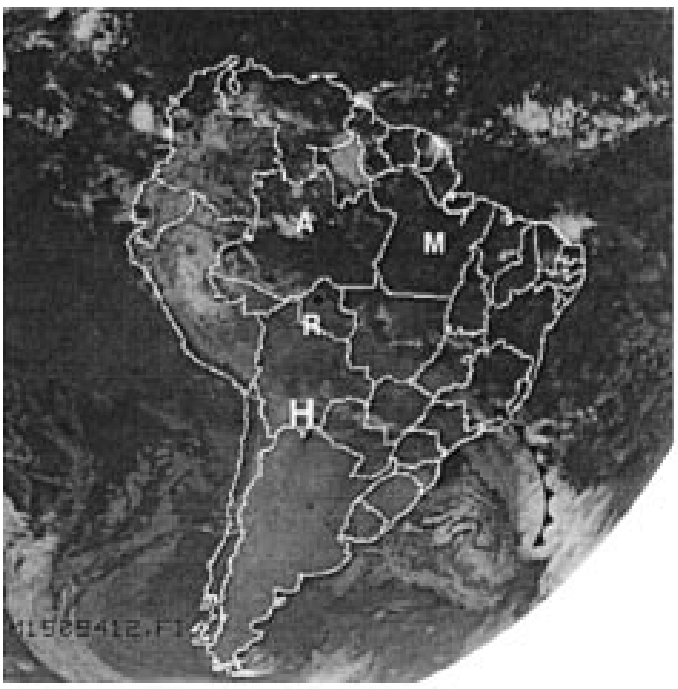

(c) $07 / 09 / 94,12$ UTC

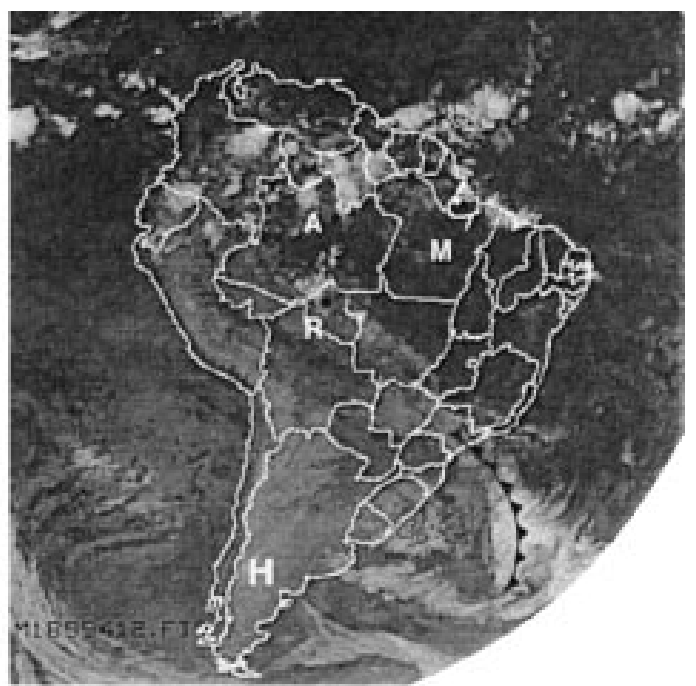

(b) $07 / 08 / 94,12$ UTC

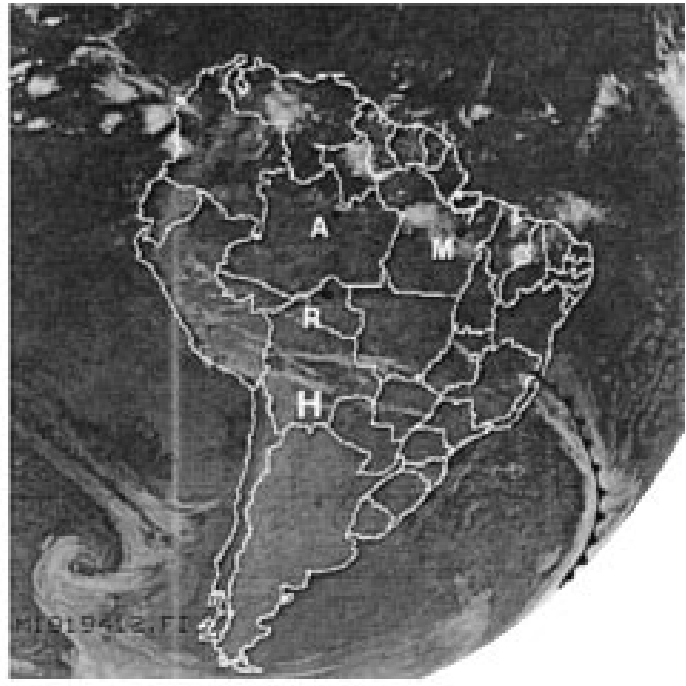

(d) $07 / 10 / 94,12$ UTC

FIG. 10. Series of GOES-8 enhanced IR images, 1200 UTC for (a) 7 July, (b) 8 July, (c), 9 July, (d) 10 July, (e) 11 July, and (f) 12 July. Surface features such as the cold front and the anticyclone $(\mathrm{H})$ are from NCEP-NCAR reanalysis from 1200 UTC. The ABRACOS sites are indicated: Manaus (A), Marabá (M), and Ji-Paraná (R).

peratures are, on average, slightly lower than at the forest sites (Culf et al. 1996), largely because the lower aerodynamic roughness (Wright et al. 1996) leads to less efficient turbulent transfer and allows the development of strong temperature inversions during the night. During the friagens, this difference in minimum temperatures between forest and deforested sites is increased, probably because the clear skies common during the friagens enhance the development of the inversions at both sites (but more at the pasture because of 


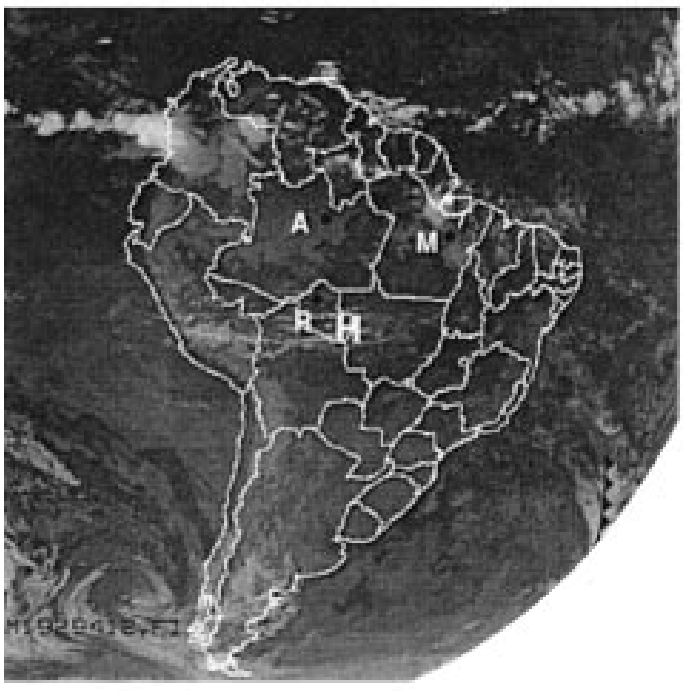

(e) $07 / 11 / 94,12$ UTC

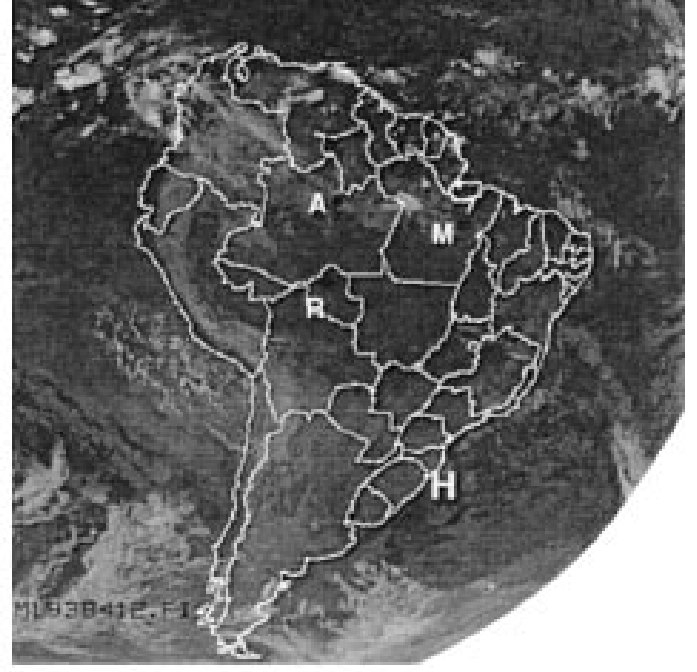

(f) $07 / 12 / 94,12$ UTC

FIG. 10. (Continued)

the less efficient turbulent transfer there), because the energy stores of the biomass and canopy space of the forests has a regulatory effect on the temperature of the air over the forest sites.

For the 26 June and 9-10 July case studies presented here, Ji-Paraná was affected by the cold air on the same day as southern Brazil. The cold air arrived in Manaus and Marabá between 2 and 3 days later and by this time is greatly modified by the underlying surface. At these locations, the air mass is best regarded as no longer "polar" but rather "tropical continental." Based on the observations of wind speed and direction and cloudiness, along with the air temperature data, it is suggested that cold-air advection is the main mechanism for cooling in Ji-Paraná where maximum and minimum air temperatures fell substantially and the sky remained cloud free. At Marabá and Manaus increased cloudiness (probably middle-level clouds or shallow cumulus), associated with the friagens, meant that the cooling took the form of reduced maximum temperatures and reduced diurnal temperature range.

It is interesting to note that this wide range of temperatures and humidities that occur in Ji-Paraná under full solar radiation conditions, as a result of the friagens, has had a practical benefit to the modeling of surface conductance in the region. When heat flux and evaporation data was being gathered in Ji-Paraná in 1993 for ABRACOS, there were several friagens. Therefore, the dataset has a large range of temperatures and humidities (much larger than would have occurred in normal Amazonia conditions). The flux data have been used to derive the surface conductance functions for inclusion in climate modeling. The wide data range meant that the dependence of surface conductance on temperature and humidity could be derived with much more certainty than has previously been the case, or is normally the case, in humid Tropics (Wright et al. 1996).

\section{Conclusions}

Detailed studies of surface and upper-air variables were made at three pairs of forested and adjacent deforested sites at three places across Brazilian Amazonia and supported by data from other stations in the rest of Amazonia and southern Brazil. The surface measurements are from a network of micrometeorological, climatological, and soil hydrology observations that started on 1990, as part of the ABRACOS experiment. In this paper, we have studied the weather conditions in these three sites as related to the friagens of 26 June and 10 July 1994. These friagens produced severe frosts in the states of southern Brazil, with temperatures in the vicinity of $0^{\circ} \mathrm{C}$ in Paraná and São Paulo, leading to estimated losses of $50 \%$ or more in the 1995-96 production of coffee in these states. The measurements presented here demonstrate that the cold air from these friagens have reached Ji-Paraná in southern Amazonia and even, albeit with much decreased intensity, Manaus in central Amazonia and Marabá in eastern Amazonia. The duration of these phenomena, from the passage of the cold front to the date when temperature and humidity return to their values previous to the passage of the front, is from 5 to 6 days, with a 2to 3-day period in the local weather that is characterized by unusually low temperatures.

The passage of the cold front associated to the friagem is detected in the variations of atmospheric pressure and humidity in the daily series during the occurrence of the phenomenon. The amplitude of the changes in surface 
weather variables (large in southern Brazil, somewhat large in Ji-Paraná, and very small in Manaus, Marabá, and other stations in central and eastern Amazonia) indicates a more intense friagem in southern than in central or eastern Amazonia. This result is confirmed by analysis of the 500-925-hPa thickness layer for the 26 June case. The thickness values decrease between 300 and $100 \mathrm{~m}$ over southern Brazil and Southern Amazonia, respectively, $24 \mathrm{~h}$ before to the coldest day, while for the other sites this reduction is not observed. This change of thickness can also be used to track the advance of the cold air from higher to lower latitudes. In addition, radiosonde observations in southern Amazonia show that during the friagem, the boundary layer is shallower and much cooler than the pre- and postfriagem days.

The impact of the friagens is felt at both the forest and the deforested sites and may affect the local flora and fauna and perhaps even the local population, all of which are adapted to warmer weather. While there is no economically important agriculture in Amazonia, the impact of the friagens there will always be less important than their sometimes devastating impacts on the coffee growing areas of southern Brazil. However, as has been shown, the phenomena are an important feature of the climate in Amazonia, particularly in the southern and western fringes of the basin where these intermittent events can substantially reduce the mean monthly temperature and humidity during the winter months.

Work in progress will deal with the energy balance over the forested and deforested sites for these and various other friagem events, as well as a study of the atmospheric boundary layer, to determine the depth of the cold air intrusion and whether the depth is the same for all sites or if there is a tendency of decreasing depth as lower latitudes are approached.

Acknowledgments. Thanks are due to Javier Tomasella and Marcos Oyama for providing access to the ABRACOS database, to Gilberto Fisch, Vern Kousky, and Pedro Silva Dias for helpful discussions on the manuscript, to Nelson Arai for providing the GOES satellite images, and to NCAR-UCAR for providing the NCEP-NCAR reanalysis. Additional thanks to Ines Moreira fron INMET, Brasilia, and to Crel. Carlos Edson of the Diretoria de Eletrónica de Proteção ao Voo from the Divisão de Aeronautica, Rio de Janiero, for providing surface and radiosonde data, respectively. This research was carried out with the support of the Conselho Nacional de Desenvolvimiento Cientifico e Tecnologico (CNPq) of the Ministerio de Ciencia y Tecnologia from Brazil through its Program RHAE for Jose A. Marengo, at the CPTEC/INPE, in Cachoeira Paulista.

\section{REFERENCES}

Algarbe, V. R., and I. Cavalcanti, 1988: Caracteristicas da Circulacão atmosferica associadas a ocorrência de geadas no sul do Brasil.
VII Congresso Brasileiro de Meteorologia, Belo Horizonte, Brazil, Sociedad Brasileira de Meterologia, 545-547.

Brinkmann, W., and M. N. Goes-Ribeiro, 1971: Air temperature in central Amazonia II. Acta Amazonnica, 1 (3), 27-32.

— zonia III. Acta Amazo̊nica, 2 (3), 28-39.

Culf, A. D., J. L. Esteves, A. de O. M. Filho, and H. Rocha, 1996: Radiation, temperature and humidity over forest and pasture in Amazonia. Amazonian Deforestation and Climate, J. H. C. Gash, C. Nobre, J. Roberts, and R. Victoria, Eds., John Wiley and Sons, $175-192$.

Dapozzo, J., and M. A. F Silva Dias, 1988: Um estudo de caso da penetracao do ar polar em latitudes baixas: Julho de 1988. VII Congresso Brasileiro de Meteorologia, Belo Horizonte, Brazil, Sociedade Brasileira de Meteorologia, 601-606.

Fisch, G., 1996: Camada Limite Amazonica: Aspectos Observacionais e de Modelagem. Rep. Tese de doutorado em meteorologia. INPE/ Brazil. $180 \mathrm{pp}$. [Available from Instituto Nacional de Pesquisas Espaciais. Av. dos Astronautas 1758, Caixa Postal 515. 12-227010 So José dos Campos, São Paulo, Brazil.]

Fortune, M., and V. E. Kousky, 1983: Two severe freezes in Brazil: Precursors and synoptic evolution. Mon. Wea. Rev., 111, 181-196.

Gash, J. H. C., C. A. Nobre, J. Roberts, and R. Victoria, 1996: An overview of ABRACOS. Amazonian Deforestation and Climate, J. H. C. Gash, C. Nobre, J. Roberts, and R. Victoria, Eds., John Wiley and Sons, 1-14.

Kalnay, E., and Coauthors, 1996: The NCEP/NCAR 40-year reanalyses project. Bull. Amer. Meteor. Soc., 77, 437-471.

Marengo, J., 1984: Estudio sinoptico-climatico de los Friajes en la Amazonia peruana. (in Spanish). Rev. Forestal Peru, 12, 55-80.

— A. Cornejo, P. Satyamurty, C. Nobre, and W. Sea, 1997: Cold surges in the tropical and Extratropical South America. The strong event in June 1994. Mon. Wea. Rev., in press.

Martin, C., D. Fitzjarrald, M. Garstang, A. Oliveira, S. Greco, and E. Browell, 1988: Structure of the mixing layer over the Amazonian rain forest. J. Geophys. Res., 93, 1361-1375.

Morize, H., 1922: Contribução o Estudo do Clima do Brasil. Ministerio da Agricultura, Industria e Commercio. Rep. Observatorio Nacional de Rio de Janeiro, 1922. 66 pp. [Available from Instituto Nacional de Pesquisas Espaciais, Sao Jose dos Campos, Caixa Postal 515, São Paulo, Brazil.]

Nobre, C., G. Fisch, H. R. da Rocha, R. F. da Lyra, E. P da Rocha, A. C. da Costa, and V. Ubarana, 1996: Observations of the atmospheric boundary layer in Rondonnia. Amazonian Deforestation and Climate, J. H. C. Gash, C. Nobre, J. Roberts, and R. Victoria, Eds., John Wiley and Sons, 413-424.

Satyamurty, P., P. Etchichury, C. Studzinsky, N. Calbete, R. Lopes, I. A. Glammelsbacher, and E. A Glammelsbacher, 1990: A primera friagem do 1990: Uma descripção sinótica (in Portuguese). Climanalise, 5 (5), 43-51.

Seluchi, M., and J. Nery, 1992: Condiciones meteorologicas asociadas a la ocurrencia de heladas en la region de Maringa (in Spanish). Rev. Brasileira Meteor., 7, 523-534.

Shuttleworth, W. J., J. H. C. Gash, J. M. Roberts, C. A. Nobre, L. C. B. Molion, and M. N. G. Ribeiro, 1991. Post deforestation Amazonian climate; Anglo-Brazilian research to improve prediction. J. Hydrol., 129, 71-85.

Serra, A., and L. Ratisbona, 1942: As massas de ar da America do Sul (in Portuguese). Rep. Ministerio da Agricultura, Serviço de Meteorologia. Rio de Janiero 1942. 32 pp. [Available from Instituto Nacional de Pesquisas Espaciais, Sao Jose dos Campos, Caixa Postal 515, São Paulo, Brazil.]

Tarifa, J., H. Pinto, R. Affonsi, and M. Pedro, 1985: A gênese dos epissodios meteorológicos de julho de 1975 e a variação espacial de danos causados pelas geadas na cafeicultura no Estado de São Paulo (in Portuguese). Ciênc. Cult., 29, 1362-1374.

Wright, I., C. Nobre, J. Tomasella, H. Rocha, J. Roberts, E. Vertamatti, A. D. Culf, R. Alvala, M. Hodnett, and V. Ubarana, 1996: Towards a parameterization for Amazonia. Amazonian Deforestation and Climate, J. H. C. Gash, C. Nobre, J. Roberts, and R. Victoria, Eds., John Wiley and Sons, 473-504. 